International Journal of English Language Studies (IJELS)

ISSN: 2707-7578

DOI: 10.32996/ijels

Website: https://al-kindipublisher.com/index.php/ijels

\title{
Sensory Details for Descriptive Writing
}

NOAH F. ACEDO

Senior High School Educator, Senior High School Department, University of Cebu - Main, Cebu City, Philippines

Corresponding Author: NOAH F. ACEDO, E-mail: nacedo@uc.edu.ph

ARTICLE INFORMATION ABSTRACT

Received: September 09, 2020

Accepted: October 12, 2020

Volume: 2

Issue: 4

DOI: 10.32996/ijels.2020.2.4.2

\section{KEYWORDS}

visualization, sensory, descriptive, realistic, creative
This study was conducted to determine the effectiveness of sensory details in writing descriptive essay to grade twelve STEM students, University of Cebu-Main Campus. The result was used as basis for a proposed action plan. Specifically, the study sought answers to the pretest performances of the control and experimental groups, the posttest performances of the control and experimental groups, the significant difference between their pretest performances, the significant difference between their pretest-posttest performances, and the significant difference between their posttest performances. A quasi-experimental design was used with the control and experimental group. There were 60 grade twelve students as subject in the study. The experimental group was taught with the use of sensory details while the control was taught using the lecture method. Pretest and posttest evaluations were used to measure the academic performance of the students in both groups. Most of the students had good level performances. The posttest scores of both groups marked an increase and the posttest mean value of the experimental group was significantly higher compared to the control group. Writing for students is more fun and engaging when they are able to actually feel, see, smell, touch, or hear what they are writing about. Sensory detailed composition writing also explores the creative skills of learners. Learners would exercise realistic yet creative way of writing a descriptive essay.

\section{Introduction}

Writing a paragraph is one of the difficulties of learners in an English class. Writing is considered uninteresting since it needs a wide vocabulary to come up with a well-structured composition. Aside from the limited vocabulary learners would usually struggle with, there are those who are overfilled with information and selecting which of these information are highly relevant to their writing. Added to this is their difficulty in organizing the information. While vocabulary is a much-needed ingredient, mastery of the basics in writing is also highly required. Sadly, learners are still not adept on this aspect. Subjectverb agreement has been a widely noticed problem. Even basic sentence construction is a concern they are grappling with. When the fundamentals of writing are hardly observed, it will be no question if learners find the succeeding steps even more difficult.

Another consideration is the learners' ability to develop the ideas put in their writing. Organizing their ideas is needed but developing these will help them build a quality writing. This requires not only their knowledge on the topic, but also their mastery on the patterns of development. This further necessitates the richness of vocabulary as previously mentioned. With proper word signals, learners can better logically sequence their ideas. A problem in writing paragraphs, and more with essays, will rise otherwise. Moreover, learners consider writing an essay a tedious job. Careful observance of the writing process is a root to this. When writing, they have to follow ten steps, from preparation to revision, from one draft to several drafts until the writing is perfected. Patience and determination are then the keys in writing effective essays. It is known that this era comprises learners who like to do things instantly; who are always in rush. Writing then becomes a great load for

K C AL-KINDI CENTER R D FOR RESEARCH AND Your gateway to world-class research
Published by Al-KindiCenter for Research and Development. Copyright (c) the author(s). This is an open access article under CC BY license (https://creativecommons.org/licenses/by/4.0/) 
them to work on. Learners find it difficult to start writing an essay for they have a lot of apprehensions such as grammar rules, credibility, relevance, organization of thoughts, and clarity of the work. These difficulties also become a challenge for educators since they need to go back to the basics of writing. Moreover, most learners do not do researches before starting the essay.

As an educator, the researcher observes that numbers of students find it complicated to start a write up especially writing a description of a thing that is not seen, heard, touched, smelled, or tasted. One factor to be considered in writing a descriptive essay is the authenticity of their expressions that come from a single piece which speaks of their experiences. Moreover, the researcher observed that the learners had difficulties in organizing their thoughts while writing descriptive essays for they keep on thinking of the grammatical rules. Nonetheless, sensory details should link to the writing skills of the learner. Sensory experiences make the students' writing style more colorful, more interesting, and more effective.

This study is an empirical effort to justify that the learners, through sensory details, will become more efficient and effective writers of descriptive essays.

\section{Theoretical Background}

This study is anchored in J.P. Guilford's structure of intellect model theory and supported by Howard Gardner's multiple intelligence theory and David Kolb's learning styles theory.

J.P. Guilford's structure of intellect model theory gives educators several useful functions. Other school districts have used the model to make their curriculum develop on its most important aspects. The structure of intellect model theory organizes the various abilities of an individual into three dimensions namely: content, product, and process. Guilford wants to come up with tests for the possibilities of combining the three dimensions. This also gives an idea that an individual could be superior on some of the abilities but inferior on others (Barlow, 2000). Guilford's original structure of intellect modes was composed of 120 components. Guilford combined the visual and auditory component in a same figural content and he mixed memory recording and memory retention in common retention.

The structure of intellect theory combines cognitions with mathematical concept to dig deeper on the nature of human intelligence. The reasoning and problem-solving skills on an individual are composed of 30 intellectual abilities out from the stated 150. This skill includes the convergent and divergent operational skills of an individual. This is calculated by multiplying six products by five contents. In addition, memory operations are made up of 30 varieties of intellectual abilities. Language skills, which are under the cognitive operations, are composed of 30 dissimilar abilities. Lastly, decision-making, which is under the evaluation operations, composed of 30 unlikely similar intellectual abilities (Pappas, 2016).

The theory of multiple intelligences asserts that (1) the nine intelligences are present to every person; (2) the intelligences of the majority can be fully developed into a more competent level; (3) the operation of the people with more intelligences are done in more complex habits; (4) the varied ways can be used by the population to fully expressed each intelligence. Howard Gardner's multiple intelligences theory can be a basis of curriculum development, planning and instructions, and suitable learning activities and methodologies. The multiple intelligences theory can be used in any context like family and school. It also provides teaching methodologies that create avenues for creative outputs, highlighting comprehension and applying newly acquired knowledge, strategies and other aspects of the teaching and learning process (Xie \& Lin, 2009).

Learner's varies learning styles can be answered when the process includes a wide scope of suitable techniques, activities, and assessments. Two of the nine bits of intelligences emphasized in Gardner's multiple intelligence are visual-spatial and linguistic intelligences. Visual-spatial intelligence speaks about individual's comprehension on a map and other graphical representation. This intelligence explains the ability to easily decipher illustrations, graphics, and visual materials. This intelligence is of a great significance for succeeding daily activities. Mathematicians, scientists, engineers, meteorologists, and architects are seen as having high visual-spatial intelligence. This intelligence requires the learners to maximize spatial skills. These learners exceedingly developed visual sense that affects their skills to understand mental representations. They like seeing images, computer graphics, and visualizing data.

Linguistic intelligence talks about the ability of an individual to comprehend information and come up with a work that includes verbal and written language, such as speeches, manuscripts, and electronic mails. This intelligence also refers the strength of an individual to use the language and express oneself through rhetoric and poetic write-ups. This intelligence requires the effective use of the language for better understanding and avoidance of misconceptions. Learners with linguistic intelligence are seen having high auditory skills and think about the words heard and created pictures in mind. They are fond 
of reading books and composing academic and literature write-ups. The instruments to be used include lectures and discussions, academic books, multimedia, and computers.

Kolb explains the four-stage learning cycle which the individual undergoes. This sub-theory thoroughly describes the individual based on the process of acquisition. The progress of the individual once passes the four stages: (1) having concrete experience, (2) observation of and reflection on the experience (3) abstract concepts and generalizations formation and (4) test the hypothesis for future situations - results to effective learning (McLeod, 2013)

Kolb's learning styles could be utilized by teachers to analytically evaluate the learning condition available to learners. This develops more suitable learning opportunities for the learners. Educators must ensure that the activities offered to the learners are designed in ways that each learner has the chance to engage themselves and make them the best. Moreover, individuals can be aided to acquire information more effectively by identifying their preferred learning styles and the strengthening of such by applying them in real life (McLeod, 2017).

Genetics, life experiences, and the environment are the factors of the individual learning styles. Moreover, Kolb developed theory of experiential learning and learning styles inventory. Different strengths and preferred styles in acquiring information are the basis of the learning style inventory. This proposes that every individual learn differently and designing learning activities based on the different learning styles of the learners can improve the teaching-learning process (Cherry, 2018).

\section{Review of Related Literature and Studies}

The initial tip for the teachers to teach the learners with the proper way of descriptive writing is giving them the chance to see something in their mind. With this, the learners find it easier to compose about (Wilhelm, 2008). Other means of teaching the learners to write descriptive expression is to put up the visual representations and bring about their life experiences which vary to every learner (Rosenblatt, 2005).

Descriptive writing through the use of sensory details should become a fundamental element of expressing one's experience inside or outside the learning environment. Learners must know that writing descriptive expression is a tool of generating authentic ideas.

The learners at the same time knowing the proper way of writing descriptive expression must understand that writing focuses on two significant themes: (1) writing is not a mere expression of thoughts into transcripts; it is a chance of discovery and expression of ideas suitably; and (2) the enhancement of wide writing strategies which is a complex course in the writers mind set a high demand on the limited operational memory (Galbraith, 2009).

The utilization of appropriate learning methodologies and techniques enables the learners to do an act and be responsible for them to learn and establish a sense of independence and self-path. These aspects are important and significant to them for the learning process doesn't stop inside the classroom but outside the formal classroom context as well. In the year 1960s and mid-1980s, researches on the language learning strategies began. Learning vocabulary has been catching EFL researchers' attention. Vocabulary is now a focal point of ESL art of teaching and research after witnessing the evident boom of numbers of publications (Mayesky, 2002).

Mental pictures are representations in the human mind of any present objects or situations. These mental pictures are not just visual representations, but the ability of a person to "hear" a sound in his head also relies on mental pictures. Thus, each of the five senses may create a mental picture (Feldman, 2003).

Teachers must be aware that engaging students in any writing activities are no easy to learners most especially if they have a difficulty in organizing their thoughts. The coherence and cohesion of the learners' write-ups depend on how the learners interpret the experience. The learners' brain cannot create a connection amongst ideas which are not kept on it. Thus, contemporary teaching demands for interacting activities, techniques, and strategies which can help the learners to accumulate ideas which appropriate and important to them. Composition teachers must know various ways of teaching descriptive writing to learners which creates genuine and true descriptive expressions (Sasil, 2016).

The English for foreign language teacher Carter (2015) has presented an effective technique for writing descriptive paragraphs. She put emphasis on the utilization of sensory details in the written outputs of the learners. 
The descriptive expression and numerous writing activities have become the common assignments of students that must be completed in their composition classes. This usual scenario in a school set-up has become the boiling point to look for techniques that best address the difficulty of the learners to write descriptive write-ups

Learners, most especially the English as foreign language learners, have mixed a longer time starting the writing assignment. Utilizing sensory details in writing is a useful technique for all educators in any EFL teaching contexts, from pre-school to tertiary education, and this can be utilized with a vast scope of texts that are certainly clear and that arouse the five senses (Carter, 2015).

Providing the learners with reading materials, short story or poem, which are colorful before the course of writing goes around and becomes thinking skills and it sparks the interests of the learners to the topic (Wilhelm, 2008).

As the educator, together with the learners, reads the passage, the learners are encouraged to visualize the words and make it into mental pictures. After reading the passage, the learners are asked to share their ideas to other learners what they have seen in their minds. Visualizing the images in the learners' mind as they read the passage, describing the individual experience and completing the table give support to learners when they scribble (Carter, 2015).

Giving names, putting details, doing comparison are the three basic strategies in describing. These strategies are used by most writers. Aside from these strategies, writers have numbers of language resources which are helpful in conveying looks, sounds, smells, touches, and tastes. It is explained that the sense of sight is having supremacy over the other senses. People depend on the sense of sight when describing, representing observations, creating verbal images or word-pictures, than the other senses. Illustrating pictures with words is the way for writers to share their perception and comprehension. Personal experience is one of the results of word-pictures. The process of illustrating word-pictures or describing as it is called, reconstructs the world as to how the writer understands it (Axelrod \& Cooper, 1985).

Maximizing sensory details gives learners the confidence they need as they are guided all throughout the reading; it also aids the learners to think while they are writing. As the learners read, they are already visualizing. The only concern is that the learners need encouragement to act on it (Dinkins, 2007).

Employing the learners to be effective writers of their personal experiences through descriptive writing that maximizing the power of sensory is one of the breeding grounds in classroom set-up. With this, the love of the learners to write what they have experienced is what the teachers need to uphold.

The mixed of visual representations and written language which put emphasis on the content of the written text are the focus of the term graphic (Evans, 2015).

The learners' personal experiences, formed into a graphic life writing projects, can be used by learning institutions to establish a new instructional space and to serve as reading materials (Marshall, 2016).

A friendly learning environment is a significant aspect of maintaining learners' engagement in the learning process. Thus, the learners' interest and willingness to learn is higher and the independence is increasing. In order to catch learners' attention, teachers must assure the relevance of the materials to keep them involved in the learning activities. Sensory details for visualization are one of the examples of the instructional techniques (Eggen \& Kauchek, 2014).

All human ideas and comprehension are powered by the complex organ, the brain. In context of education, the brain plays a significant role in literacy and visualization. A short analysis of brain, education, and visualization' connection results to a much greater knowledge of literacy and visualization (Erin, 2008).

Berninger et al. (2002) stated that how the students learn; the brain system plays a vital role. The writing brain depends on mental faculties, language, and the ability of the person to write.

Over the course of the numbers of researches with regard to drawing and its connection to mental activity, Sheridan (1990) explained that drawing is fundamental to person's mental activities. Based on the observations of Sheridan, she established the scribble hypothesis which is a strand of hypotheses. The third and fourth hypotheses are undeniably associated to each other. The third hypothesis suggests that young children's writing aids them to carry out and arrange shapes or thinking patterns. This offers that drawing and formulating mental pictures or visual representations of the child's feelings, personal experiences, and observations are essential in the development of their cognition. The fourth hypothesis assumes that thirty young children's writing emboldens an attraction for drawing, which sets the mind for acquiring knowledge. 
Jenson (2001) explained that for the learners to visualize and make actions, utilization of sensory details is a unique and effective tool. These observations embrace the idea that five senses result constructive outcomes on literacy.

\section{Related Studies}

In the study conducted by Kindler (2013), the I.Q. scores of the learners have consistently improved over the few decades, and almost of the population that increased were attributed to the visual-spatial domains. Arts, involving the bodilykinaesthetic domain, activate inactive parts of the brain. Learners' cognitive improvement may get benefits from the inclusions of visual imagery that relies on the movement and gesture.

Teachers are said to be effective in integrating varied writing strategies to learners for a better composition. The use of learners' imagination in the process of writing is suggested to put the learners to a more realistic context. This is also to maintain the authenticity of the learners' descriptive write-up.

Baer (2005) used Symbolic Reading Inventory (SRI) interview methodology which is incorporated to thoroughly comprehend sensory details in the process of writing. Baer's learners utilized patterns to represent characters, emotions, and scenarios which aided her understanding of how the students think, analyze, and interpret passages.

Baer (2005), in her study, developed four coding strategies. She indicated that learners felt and expressed an allencompassing use of their imagination to draw out meaning and create their own visual representations out from the passage they read. She stated that reading is complicated puzzle composed of myriad pieces which some fit easily while the others struggle to fit in. She explained that the learners created snap scenes from the materials they used for reading and situated themselves in the picture in mind.

Baer (2005) voiced that the learners are engaged in the personal imaginations, entering themselves in the doors of the texts they heard, saw, felt, tasted aspects of their chosen situations. Moreover, the learners did not only bring into life the texts they read but also put their own breathing in the texts as they make part in the process of creative meaning. Lastly, she found out that the educators must provide realistic scenarios that touch and move the learners into an extraordinary place than the common.

Macy (2004) found out that stressing out on sensory details, relevant to various context and circumstances, adds to the learners' layer of comprehension of the texts. The comprehension is the result of the wide scope of concrete models which the sensory presentations have provided.

In the study of Parsons (2006) used of memory work, group works, and visual procedures emboldens the transmediation of written, verbal, and figurative representations. Metaphors are maximized in sensory details within the passage to formulate mental pictures. Sensory details in visualization shaped the viewpoint which the learners' see the story world.

Erin (2008) asserted that visual literacy may help students construct meaning when reading and writing, but what about teachers who utilize visual literacy practices in their classrooms.

The Canadian middle school-level learners gave their point of view in the utilization of visualization in the lessons gives positive influence in their learning. The learners' examined, assessed, and appreciated visuals (Begoray, 2001).

This study aimed to demonstrate to the readers that composing descriptive expression in an English class is something enjoyable and interesting for it allows the learners to express their feelings about a certain memorable experience. Learners should be able to air out their ideas and create images in their minds. Let this be an avenue for learners to value and establish interest in a genuine and true writing.

\section{Research Problem}

The study determined the effectiveness of sensory details in writing descriptive essays to Grade 12 STEM students, University of Cebu - Main Campus. The findings served as the basis of a proposed action plan.

Specifically, the study answered the following questions:

a) What are the pretest performances of the control and experimental groups?

b) What are the posttest performances of the control and experimental groups?

c) Is there a significant difference between the pretest performances of the control and experimental groups? 
d) Is there a significant difference between the pretest and posttest performances of the control and experimental groups?

e) Is there a significant difference between the posttest performances of the control and experimental groups?

f) Based on the findings, what action plan can be proposed?

\section{Methodology}

The study used the quasi-experimental method in determining the performance scores of the control and experimental groups. The subjects of the study were 60 Grade 12 STEM students. Thirty students served as the control group and the other thirty served as the experimental group. Table 1 shows how the matching of the subjects was conducted. The main instruments that the researcher used was an attractive picture of a Filipino dish from the Chinese heritage, Chow Mein.

A rubric was used with these criteria: introduction, sentence structure, and grammar, spelling, capitalization, and punctuation. The second part of the rubric provided the criterion: sensory details and word choice. The teaching procedure and activity in the control group were done by means of free style descriptive writing. Sensory details in writing were used for the experimental group.

The researcher submitted to the principal of the Senior High School Department a letter requesting permission to conduct the study. Upon the approval of the request, the researcher started getting the participants' age, gender and their final grades. After matching the subjects of the two groups, an introduction to descriptive writing was given to each group to measure the students' prior knowledge on the topic. This was given to the two groups on the same day but of different subject encounter time. After, the topics were introduced to the two groups. A realistic situation of $\boldsymbol{a}$ family eating chow mein was used to stimulate their writing. For the pretest, writing was limited to writing per se. Prior to the writing, both control and experimental groups discussed the elements of writing description. The experimental group utilized Katherine Carter's Five-Sense Table and Sensory Details Word Lists were introduced to the experimental group which helped in guiding them to make an interesting five-sense description. On the last sessions of the control and experimental groups, the control group did their post-writing activity without any stimulus while the experimental group did the writing activity with a stimulating chow mein picture. The outputs gathered were assessed by the three experts in writing identified as Evaluator 1 , who is an instructor in Cebu Normal University specializing in English courses, Evaluator 2 is a research coordinator at University of Cebu - Senior High School, and Evaluator 3 is a language and literature instructor at University of Cebu - Main. Grading of the essays was based on the rubric.

\section{Results and Discussion}

Pretest Performances of the Control and Experimental Groups

Table 1. Pretest Performances of the Control Group and Experimental Group

\begin{tabular}{|c|c|c|c|c|c|c|c|}
\hline Criteria & Evaluator & Mean & $\begin{array}{l}\text { Final } \\
\text { Rating }\end{array}$ & Description & Mean & Final Rating & Description \\
\hline \multirow{3}{*}{ Introduction } & Number 1 & 14.70 & \multirow{3}{*}{12} & \multirow{3}{*}{ Good } & 13.27 & \multirow{3}{*}{13} & \multirow{3}{*}{ Good } \\
\hline & Number 2 & 9.47 & & & 11.27 & & \\
\hline & Number 3 & 11.17 & & & 13.50 & & \\
\hline \multirow{3}{*}{$\begin{array}{c}\text { Sensory Details } \\
\text { and } \\
\text { Word Choice }\end{array}$} & Number 1 & 13.64 & \multirow{3}{*}{12} & \multirow{3}{*}{ Good } & 12.92 & \multirow{3}{*}{13} & \multirow{3}{*}{ Good } \\
\hline & Number 2 & 10.59 & & & 11.84 & & \\
\hline & Number 3 & 10.94 & & & 12.30 & & \\
\hline \multirow{3}{*}{$\begin{array}{l}\text { Sentence } \\
\text { Structure }\end{array}$} & Number 1 & 13.03 & \multirow{3}{*}{11} & \multirow{3}{*}{ Good } & 11.63 & \multirow{3}{*}{12} & \multirow{3}{*}{ Good } \\
\hline & Number 2 & 11.67 & & & 10.97 & & \\
\hline & Number 3 & 12.13 & & & 12.53 & & \\
\hline \multirow{3}{*}{$\begin{array}{c}\text { Grammar, } \\
\text { Spelling, } \\
\text { Capitalization, } \\
\text { and Punctuation }\end{array}$} & Number 1 & 12.90 & \multirow{3}{*}{11} & \multirow{3}{*}{ Good } & 13.47 & \multirow{3}{*}{12} & \multirow{3}{*}{ Good } \\
\hline & Number 2 & 10.07 & & & 10.50 & & \\
\hline & Number 3 & 10.80 & & & 13.30 & & \\
\hline \multicolumn{3}{|c|}{$\begin{array}{r}\text { Overall } \\
\text { Description }\end{array}$} & 12 & Good & $\begin{array}{l}\text { Overall } \\
\text { Descript } \\
\text { ion }\end{array}$ & 13 & Good \\
\hline
\end{tabular}


Table 2 shows that performances of the control group in the pretest are equal in all categories - introduction, sensory details, word choice, sentence structure, and grammar, spelling, capitalization, and punctuation. This explains that the respondents are aware of the basics in writing an essay. The control and experimental show good results in writing a descriptive essay.

Rolls and Wignell (2013) presented parts of a well-structured introduction for the writers to consider. These parts are the following: background information, thesis statement, outline, and scope. These also served as framework for the writers to catch the readers' interest.

It also reveals a small difference in the final rating of the experimental group in all criteria. The final ratings of the respondents show that the respondents have a prior knowledge on writing descriptive essay. Moreover, criteria 1 and 2 have same rating which means that the respondents are showing more interesting situation in the introduction and utilization of the five senses.

Posttest Performances of the Control and Experimental Groups

Table 2. Posttest Performances of the Control and Experimental Groups

\begin{tabular}{|c|c|c|c|c|c|c|c|}
\hline Criteria & Evaluator & Mean & $\begin{array}{c}\text { Final } \\
\text { Rating }\end{array}$ & Description & Mean & Final Rating & Description \\
\hline \multirow{3}{*}{ Introduction } & Number 1 & 15.43 & \multirow{3}{*}{15} & \multirow{3}{*}{ Good } & 15.90 & \multirow{3}{*}{16} & \multirow{3}{*}{ Very Good } \\
\hline & Number 2 & 15.30 & & & 15.60 & & \\
\hline & Number 3 & 14.67 & & & 17.63 & & \\
\hline \multirow{3}{*}{$\begin{array}{c}\text { Sensory Details } \\
\text { and } \\
\text { Word Choice }\end{array}$} & Number 1 & 15.27 & \multirow{3}{*}{15} & \multirow{3}{*}{ Good } & 15.30 & \multirow{3}{*}{16} & \multirow{3}{*}{ Very Good } \\
\hline & Number 2 & 14.47 & & & 15.24 & & \\
\hline & Number 3 & 13.22 & & & 17.60 & & \\
\hline \multirow{3}{*}{$\begin{array}{l}\text { Sentence } \\
\text { Structure }\end{array}$} & Number 1 & 14.47 & \multirow{3}{*}{14} & \multirow{3}{*}{ Good } & 14.20 & \multirow{3}{*}{15} & \multirow{3}{*}{ Good } \\
\hline & Number 2 & 14.04 & & & 14.47 & & \\
\hline & Number 3 & 12.83 & & & 17.13 & & \\
\hline \multirow{3}{*}{$\begin{array}{c}\text { Grammar, } \\
\text { Spelling, } \\
\text { Capitalization, } \\
\text { and Punctuation }\end{array}$} & Number 1 & 14.40 & \multirow{3}{*}{14} & \multirow{3}{*}{ Good } & 15.03 & \multirow{3}{*}{16} & \multirow{3}{*}{ Very Good } \\
\hline & Number 2 & 14.30 & & & 14.10 & & \\
\hline & Number 3 & 14.40 & & & 18.43 & & \\
\hline \multicolumn{3}{|c|}{$\begin{array}{r}\text { Overall } \\
\text { Description }\end{array}$} & 15 & Good & $\begin{array}{l}\text { Overall } \\
\text { Descripti } \\
\text { on }\end{array}$ & 16 & Very Good \\
\hline
\end{tabular}

Table 2 shows an improvement in terms of the final rating. Criteria 1 and 2, introduction and sensory details and word choice, reveal a good advancement after knowing the technicalities of writing a descriptive essay. This gives the idea that writing a descriptive essay needs to have catchy introduction for the readers to be more interested in the write-up as well as for the utilization of the five senses. Criteria 3, 4, and 5 namely: word choice, sentence structure, and grammar, spelling, capitalization, and punctuation are also ideal. The following reveal the progress of the learners in writing sentences that consider the rules in writing.

Table 2 displays a great improvement of the respondents in the 4 criteria, introduction, sensory details and word choice, and grammar, spelling, capitalization, and punctuation. This also reveals that the respondents are even more aware about how authenticity and showing of clear image affect the entire write-up.

Erin (2008) explained that educators have used varied teaching strategies, including the use of sensory details, to increase comprehension of the beginner readers. In addition, she pointed out that sensory details have become part of the pillars of arts and literacy. Educators have utilized sensory details for the learners to make meanings of the text and improve reading comprehension.

Thus, emphasizing sensory details for a genuine situation in mind makes the respondents an effective writer of descriptive essay. The progress in the sensory details and word choice explains that the respondents are utilizing their senses better to make it more real to the readers. The grammar, spelling, capitalization, and punctuation reveal a great change of state; this 
explains that they can play with the words that can create more lively situations through the sentences constructed by the respondents.

Difference of the Pretest Scores of the Control and Experimental Groups

Table 3. Significant Difference of the Pretest Scores of the Control and Experimental Groups

\begin{tabular}{|c|l|c|c|c|c|c|c|}
\hline Variables & Group & Mean & t-Computed & t-Critical & p-value & $\begin{array}{l}\text { Decision } \\
\text { on } \mathbf{H}_{\mathbf{o}}\end{array}$ & Interpretation \\
\hline $\begin{array}{c}\text { Pretest } \\
\text { Scores }\end{array}$ & Control & 58.30 & \multirow{2}{*}{1.74} & 2.00 & 0.09 & $\begin{array}{l}\text { Failed to } \\
\text { Reject } \mathrm{H}_{\circ}\end{array}$ & $\begin{array}{l}\text { No Sorignificant } \\
\text { Difference }\end{array}$ \\
\hline
\end{tabular}

Table 3 presents no difference between the pretest performances of the control and experimental groups of the grade 12 STEM students on the descriptive writing topic in English 4 classes. This discusses the idea that both control and experimental groups are the same with their skills in writing descriptive essay.

Zeigler (2005) stated that the power of sensory details is not given importance by the students which leads to the misunderstanding on the creation of a more detailed mental image in response to the passage.

Carter (2015) explained that $21^{\text {st }}$ century educators can keep searching for more means to activate the first-hand experiences of the learners and bring them into paper. With this, the learners can establish their experiences and visual remark when they talked about their past memories.

Difference of the Pretest and Posttest Scores of the Control and Experimental Groups

Table 4. Significant Difference of the Pretest and Posttest Scores of the Control and Experimental Groups

\begin{tabular}{|c|c|c|c|c|c|c|c|}
\hline Variables & Group & Mean & t-Computed & t-Critical & p-value & $\begin{array}{c}\text { Decision } \\
\text { on } \mathrm{H}_{\mathrm{o}}\end{array}$ & Interpretation \\
\hline Pretest & \multirow{2}{*}{ Control Group } & 58.30 & \multirow{2}{*}{10.81} & \multirow{2}{*}{2.04} & \multirow{2}{*}{0.00} & \multirow{2}{*}{ Reject $\mathrm{H}_{\mathrm{o}}$} & \multirow{2}{*}{$\begin{array}{l}\text { Significantly } \\
\text { Different }\end{array}$} \\
\hline Posttest & & 71.96 & & & & & \\
\hline Pretest & \multirow{2}{*}{$\begin{array}{l}\text { Experimental } \\
\text { Group }\end{array}$} & 61.50 & \multirow{2}{*}{17.15} & \multirow{2}{*}{2.042272} & \multirow{2}{*}{0.00} & \multirow{2}{*}{ Reject $\mathrm{H}_{\circ}$} & \multirow{2}{*}{$\begin{array}{l}\text { Significantly } \\
\text { Different }\end{array}$} \\
\hline Posttest & & 79.57 & & & & & \\
\hline
\end{tabular}

Table 4 presents significant difference between the pretest and posttest scores of the control group and the pretest and posttest scores of the experimental group.

According to Wilhelm (2008), sensory details must be used as stepping stone for the amateur writers to awaken their thinking skills. Thus, writers must apply sensory details in order to have a higher level of understanding.

Rosenblatt (2005) coined the transaction of reading which explains that no learners are alike in illustrating the exact same image. This points out that the writer must take ownership of their text and applying sensory details in writing offers remedy to the amateur writers to become more active thinkers. Hence, writers must not consider the written words as scary and alien for they are tools to be consistently used.

Table 4 clearly explains that for the control group there is improvement after having the discussion on the concepts of descriptive essay; whilst, the results of the experimental group reveals great advancement after implementing the writing strategy, sensory details, in their discussion on descriptive essay.

Difference of the Posttest Scores of the Control and Experimental Groups

Table 5. Significant Difference of the Posttest Scores of the Control and Experimental Groups

\begin{tabular}{|c|l|c|c|c|c|c|l|}
\hline Variables & Group & Mean & t-Computed & t-Critical & p-value & $\begin{array}{c}\text { Decision } \\
\text { on } \mathbf{H}_{\mathbf{o}}\end{array}$ & \multicolumn{1}{|l}{ Interpretation } \\
\hline $\begin{array}{c}\text { Posttest } \\
\text { Scores }\end{array}$ & Control & 71.96 & 4.22 & 2.00 & 0.00 & Reject $\mathrm{H}_{\mathrm{o}}$ & $\begin{array}{l}\text { Significantly } \\
\text { Different }\end{array}$ \\
\cline { 2 - 7 }
\end{tabular}


The results show that sensory details can be an effective strategy to maximize the imagination of an individual. The learners while writing a descriptive essay might expand their language to the point that authenticity is maintained in the essay. This also creates a room for utilizing properly the senses that also add to the creative way of using the words. The creative thinking skills of an individual are also enhanced as part of sensory details.

Table 5 vividly illustrates how important for a $21^{\text {st }}$ century educator to cater the individual differences of the learners in the learning arena in order to ignite their interests and be real critical thinkers. Thinking skills becomes more intrinsic part of an individual if the motivation by the English educators is done thoroughly (Sternberg, 1985; Gardner, 1983). This study, therefore, supports the importance of multiple intelligences for a more successful academic venture.

Donald (2003) claimed that sensory details have been widely used in sports for the past 30 years but can also be applied in language learning, specifically writing. He stated that sensory details are the creation of picture in the mind, real or unreal; moreover, it also touches the maximization of visual images, images of sound, actions, touch, taste, and smell. He also asserted that using sensory details is a powerful tool for the learners to activate their ability to create varied sensory images in writing.

Dinkins (2007) asserted that utilizing sensory details in writing is a great start for the learners to compose in their comfort area and have freedom to start the creative process of writing. When the learners are comfortable to seeing pictures while writing, they can immediately see what they are supposed to compose and feel more confident in translating their drawn images into words.

Furthermore, the respondents' abilities and potential are knotted to individuals' learning styles; thus, it explains that the desired results would lie in the people's way of blending of skills in writing descriptive essays. The visual component of Guilford's SI and the spatial and linguistic intelligences of Gardner served as strong foundations to achieve greater performance in writing descriptive essays that maximizes sensory details.

\section{Conclusion}

This study is an empirical effort to justify that the learners, through sensory details, will become more efficient and effective writers of descriptive essays. The writing strategy of the learners of the experimental group using visualization is effective. Furthermore, students' descriptive writing ability aided with visualization improves to a more authentic writing. In addition, writing for students is more fun and engaging when they are able to actually feel, see, smell, taste, or hear what they are writing about. Sensory detailed composition writing also explores the creative skills of learners.

\section{Limitations of the Study}

This study does not provide a clearer selection of respondents that affect the result of the intervention. Researcher had not, for example, taken into consideration the intelligent quotient of the respondents. In other words, the respondents have a better foundation in writing a few types of essays. Furthermore, the program of the selected respondents were, somehow, not matching to the activity conducted. Despite the fact that the desired result was achieved, it is sensible to consider the intelligence and programs of the respondents to gather more valid data.

\section{Suggestions}

In the light of the findings, the following suggestions for future research are given:

1. Future researchers may use fiction and non-fiction materials for the respondents to read for an improved utilization of their senses and visualization skill.

2. Future researchers may consider the programs of the respondents to establish appropriateness of the instrument and gather more valid data.

3. Future researchers may consider respondents from a lower level to evaluate their writing skills utilizing the five senses and visualization.

4. Future researchers may use real-life situations as their source of information for their descriptive compositions.

5. Future researchers may craft an action plan for teachers to apply in their writing classes. 


\section{About the Author}

Noah F. Acedo is a Senior High School Faculty at the University of Cebu - Main Campus teaching English for Academic and Professional Purposes and Inquiries, Investigation, and Immersion for grades 11 and 12. He has been teaching in the department for three years. He earned his college degree at the University of Cebu - Main Campus with the degree of Bachelor in Secondary Education with a specialization in English in 2016. He earned his master's degree at the University of Cebu - Main Campus in 2018. During his master's program, he was awarded as the Best Research Presenter for the annual University of Cebu Graduate School Research Colloquium. He presented his two research papers during the International Research Congress in Cebu organized by American Studies Association. He is currently studying at the University of San Jose Recoletos for his Doctor of Philosophy in English with a concentration in Language.

\section{References}

[1] Axelrod, R.B. \& Cooper, C.R. (1985). The St. Martin's guide to writing. New York: St. Martin's Press.

[2] Baer, A.L. (2005). Do you hear voices? A study of the symbolic reading inventory. Journal of Adolescent \& Adult Literacy, 49(3), 214-225.

[3] Barlow, C.M. (2000). Guilford's structure of the intellect. The Co-creativity Institute, (630), 221.

[4] Begoray, D.L. (2001). Through a class darkly: Visual literacy in the classroom. Canadian Journal of Education, 26(2), $201-217$.

[5] Berninger, V.W. et al. (2002). Writing and reading: Connections between language by hand and language by eye. Journal of Learning Disabilities, 35(1), 39-56.

[6] Carter, K. (2015). Teaching descriptive writing through visualization and the five senses. English Teaching Forum. https://americanenglish.state.gov/english-teaching-forum

[7] Cherry, K. (2018). Learning styles inventory types and their uses. :// www.verywellmind.com/what-is-a-learning-style-inventory2795159.

[8] Dinkins, E. (2007). They have to see it to write it: Visualization and the reading-writing connection. National Writing Project. http://www.nwp.org/cs/public/print/resource/2481.

[9] Donald, R. (2003). An Introduction to using visualisation. https://www.teachingenglish.org.uk/article/introduction-using-visualisation.

[10] Eggen, P. \& Kauchek, D. (2014). Educational psychology. England: Pearson Education Ltd.

[11] Erin, J. K. (2008). Visualization in the writing process: a case study of struggling k-4 learners in a summer writing camp. https://krex.kstate.edu/dspace/bitstream/handle/2097/615/ErinJurand2008.pdf?sequence=1.

[12] Evans, J. (2015). Challenging and controversial picturebooks: Creative and critical responses to visual texts. New York, NY: Taylor \& Francis.

[13] Feldman, R. (2003). Educational psychology. Boston: McGraw Hill.

[14] Galbraith, D. (2009). Cognitive models of writing. German Foreign Language Journal, (3), 1-23.

[15] Gardner, H. (1983). Framed of mind: The theory of multiple intelligences. New York. Basic Books.

[16] Jenson, E. (2001). Arts with the brain in mind. VA: Association for Supervision and Curriculum Development.

[17] Kindler, A.M. (2003). Commentary: Visual culture, visual brain, and (art) education. Studies in Art Education, 44(3), $290-296$.

[18] Macy, L. (2004). A novel study through drama. Reading Teacher, 58(3), 240-248.

[19] Marshall, E. (2016). Counter-storytelling through graphic life writing. Language Arts, 94(2), 79.

[20] Mayesky, M. (2002). Creative activities for young children. Australia: Del Mar Thomson Learning.

[21] McLeod, S.A. (2013). Kolb - learning styles. http://cei.ust.hk/files/public/simplypsychology_kolb_learning_styles.pdf.

[22] McLeod, S. A. (2017). Kolb - learning styles. https://www.simplypsychology.org/learning-kolb.html.

[23] Pappas, C. (2016). The structure of intellect: Everything e-learning pros need to know. http://info.alleninteractions.com/the-structureof-intellect-everything-e-learning-pros-need-to-know.

[24] Parsons, L.T. (2006). Visualizing worlds from words on a page. Language Arts, 83(6), 492-500.

[25] Rolls, N. \& Wignell, P. (2013). Communication at university: Skills for success. Australia: Charles Darwin University Press.

[26] Rosenblatt, L. (2005). Making meaning with texts: Selected essays. NH: Heinemann Educational Books.

[27] Sasil, L.V. (2016). Formulae poems for enriching writing in the English classroom. (Unpublished master's thesis). University of Cebu.

[28] Sheridan, S.R. (1990). Drawing/writing: A brain research-based writing program designed to develop descriptive, Analytic and inferential thinking skills at the elementary school level. (Unpublished doctoral dissertation). University of Massachusetts, Amherst.

[29] Sternberg, R.J. (1985). Beyond IQ: A triarchic theory of human intelligence. New York: Cambridge University Press.

[30] Wilhelm, J. D. (2008). "You gotta be the book": Teaching engaged and reflective reading with adolescents. New York: Teachers College Press.

[31] Xie, J. C. \& Lin, R. (2009). Research on multiple intelligences teaching and assessment. Asian journal of management and humanity sciences, 4(2-3), 106-124.

[32] Zeigler, L. (2005). Unleashing the power of visualization for the content areas. Kansas Journal of Reading, 21, 39-44. 